НН Інституту євроінтеграцุійних досліджень ДВНЗ «Ужгородський національний університет»

\title{
ЄВРОІНТЕГРАЦІЙНИЙ ПОТЕНЦІАЯ УКРАЇНИ В КОНТЕКСТІ ДОСВІДУ КРАЇН В-4
}

У статті розкрито особливості партнерства між Украйною та Вишеградською групою на сучасному етапі розвитку міжнародних відносин. Облрунтовано потребу переосмислення функцій Вишеграду та проаналізовано основні інструменти розвитку взаємовигідних відносин у форматі Украйна-«Вишеград+». Розглянуто можливість використання Україною євроінтеграційного досвіду країн Вишеградської четвірки. Подано висновки та рекомендації щзодо вироблення взаємовигідного формату співпраці країн Вишеградської групи та Украӥни.

Ключові слова: Украйна, Вишеградська група, євроінтеграція, регіональна співпраця, формат Украйна-«Вищеград+».

The article deals with the features of a partnership between Ukraine and the Visegrad Group in the current development of international relations. Substantiates the need to reconsider functions of the Visegrad and analyzes the main development instruments of mutually beneficial relations in the format Ukraine- "Visegrad+". Author has examined the opportunity of the Visegrad Four Eurointegration experience using for Ukraine. Also, the article shows conclusions and recommendations of the Visegrad Group and Ukraine on developing mutually beneficial forms of cooperation.

Keywords: Ukraine, Visegrad Group, European integration, regional cooperation, Ukraine-"Visegrad+" format. 
Европейська інтеграція була проголошена ключовим зовнішньополітичним курсом України, що відкриває нові можливості для економічного розвитку, соціального прогресу, співпраці з промислово розвиненими країнами світу, зміцнення позицій держави на міжнародній арені. Входження країн Центральної та Східної Европи до Европейського Союзу - один з епізодів (достатньо вагомих) гігантської трансформації міжнародно-політичного, економічного, культурного життя кінця XX - початку XXI століття.

Курс на євроінтеграцію є об'єктивною потребою для України, яка потребує надходження західних технологій та інвестицій, модернізації країни, дотримання базових демократичних стандартів, необхідних для позитивного іміджу країни у світовому співтоваристві, що відповідно сприятиме погдибленню відносин між ЕС та Україною. Країни-члени Вишеграду також висловидися за синхронізацію своїх двосторонніх відносини з Україною в контексті європейського інтеграційного процесу [3]. Держави В4 надають відчутну політичну підтримку євроінтеграційному курсу нашої держави в рамках так званої «групи друзів» України в СС, під час головування в Евросоюзі офіційно підтримуючи План дій Україна-СС. Одночасно співпраця ведеться у різних формах: зміцнення міжурядових контактів, урізноманітнення заходів у форматі «В4+Україна» у політико-безпековій, військовій, енергетичній, соціокультурній сферах, а також на регіональному рівні.

У цьому контексті корисним і навіть інструментальним є досвід центральноєвропейських країн. Успішність втілення європейського проекту країнами, що формують Вишеградську четвірку, пояснюється, насамперед, прагненням цих народів стати складовою єдиної Европи, зокрема його чотирма складовими:

1) культурною (відданість європейській культурі, зокрема цінностям);

2) політичною (європейська інтеграція розглядалася як індикатор демократизації, зокрема консолідації цього режиму); 
3) економічною (бажання долучитися до кдубу успішних країн);

4) безпековою (формування системи взаємозалежності між європейськими країнами, які б унеможливили виникнення конфліктів) [3].

Одним з важливих для України та країн Вишеградської четвірки є питання транскордонного та міжрегіонального співробітництва. Таке співробітництво розглядається сторонами як складова загального европейського інтеграційного процесу. В грудні 2005 р. в м. Братислава за принципово новими стандартами було укладено Угоду між Кабінетом Міністрів України і Урядом Словацької Республіки про транскордонне співробітництво.

У цьому контексті, зокрема у період з 2004 по 2006 рр., Европейська Комісія запропонувала Україні розпочати «сусідські програми» 3 метою більш плідного прикордонного співробітництва України з ЕС. Реалізація цих програм сприяла продовженню активної роботи України та країн Вишеградської четвірки з Европейською Комісією. Відповідно до представленого списку «сусідських програм» Україні було запропоновано участь у трьох із них:

1) співробітництво України, Польщі та Білорусі;

2) співробітництво Угорщини, Словаччини та України;

3) співробітництво України 3 країнами Центральної та Східної Европи (CARDS).

Для центральноєвропейських країн процес вступу до ЕС був полегшений, у тому числі завдяки регіональній співпраці в рамках Вишеградської групи, яка виконувала роль форуму з вироблення спільних політичних позицій, певного обміну успішними практиками, незважаючи на існуючі конфлікти між учасниками об'єднання та сприйняття один одного як конкурентів у доступі до деяких європейських ресурсів і можливостей. Враховуючи цю інтеграційну ефективність групи В4, 3 початку 2010-х Україна демонструвала зацікавленість у розширенні співпраці з нею включно 3 набуттям членства. Однак цей шанс був втрачений через затяжну фі- 
нансово-економічну кризу, негативну позицію Росії, власне щодо вступу «четвірки» до СС, а, отже, вихід на інший рівень стратегічних завдань.

Розпочинаючи 3 цього десятиліття, основним пріоритетом України у відносинах 3 центральноєвропейськими сусідами постає і має задишатися завдання, пов'язане із здобуттям європейської перспективи, зокрема це підписання і набуття чинності Угоди про асоціацію з ЕС (2014 р.) [3].

Процес економічної інтеграції та політичної асоціації України з Европейським Союзом неможливий без надійної підтримки з боку наших європейських друзів і справжніх адвокатів України всередині СС, якими, без перебільшення, є країни В4. Тим більше, що така інтеграція має будуватися саме на посиленні регіонального складника співробітництва [1]. Лише в такий спосіб, використовуючи євроінтеграційний досвід Угорщини, Польщі, Чехії та Словаччини, отримуючи експертну, дорадчу та технічну допомогу цих держав, ми матимемо можливість впевнено споглядати європейське майбутне України.

Значний потенціал має також секторальна інтеграція 3 країнами Вишеградської групи, особливо в таких важливих напрямах, як судова реформа та реформа правоохоронних органів; наближення до галузевих політик ЕС; розвиток регіональних енергоринків; заходи 3 енергозбереження; розширення контактів між людьми [5, с. 114].

У руслі політики східного виміру ЄС Вишеградською групою був запроваджений формат «В4+», який полягає у запрошенні представників України на робочі засідання «четвірки», зустрічі прем'єр-міністрів центральноєвропейських країн. У другій половині 2000-х років, окрім визначення як пріоритету підписання асоціації між Европейським Союзом та східноєвропейськими країнами, об'єднання надавало допомогу у реалізації Плану Україна - ЕС, розробленні ідеї створення зони вільної торгівлі.

Водночас упродовж останніх років ініціативи країн В-4 вже стали об'єктом уваги європейських «важковаговиків» 
та наднаціональних інститутів, зокрема беручи до уваги їх прагнення поєднати євроатлантичні та європейські інтереси в умовах латентного геоекономічного та політичного конфлікту, що сформувався між США та Европою [4].

За час співробітництва у форматі «Вишеград плюс» держави Вишеградської групи зробили чималий внесок у справу успішності просування східноєвропейських країн євроінтеграційним курсом. Сдід нагадати, що наприкінці 2012 - початку 2013 рр. країни Вишеграду в офіційних заявах закликали Европейську Комісію та Европейську службу зовнішніх дій включити у “Дорожню карту» Східного партнерства, яка готувалася до Вільнюського форуму, таке середньострокове завдання, як інтеграція найбільш успішних східноєвропейських партнерів у внутрішній європейський ринок і створення спільної економічної зони, передбачивши для його реадізації відповідні інструменти та ресурси.

Найважливішими пріоритетами у співробітництві нашої держави в рамках формату «Вишеград плюс» $\mathrm{E}$ [5, с. 119]:

1) просування спільних довгострокових інтересів щодо укладання взаємно вигідних контрактів у сфері енергетики, враховуючи потребу України в диверсифікації поставок енергоносіїв із Росії й вивільнення ресурсів українських газосховищ, кооперація в перспективних проектах добування сланцевого газу, поклади якого є на території Польщі, Угорщини, Аитви, Румунії, Болгарії та України;

2) розширення співробітництва у сфері оборони та безпеки, зокрема залучення України до Вишеградської бойової групи $\mathrm{EC}$, яка має стати повноцінним воєнно-політичним механізмом із формально окремими від НАТО повноваженнями, до участі в якій вже була запрошена наша держава;

3) подальше просування ініціатив «Вишеград плюс» у рамках програми «Східного партнерства» у східний та південний регіони України з широким залученням організацій громадянського суспільства, зокрема від- 
повідного форуму Східного партнерства, а також наукових та навчальних закладів і неурядових структур України до формування та реалізації європейської політики;

4) відкриття для партнерів агентств і програм, зокрема молодіжних та освітніх, культурного обміну тощо.

3 іншого боку, політична співпраця також повинна опікуватися зняттям існуючих бар'єрів. 3 цієї точки зору застосування інструменту Вишеград+, запрошення українських найвищих політичних представників на деякі засідання і саміти В4, ведення діалогу в форматі В4 + Україна (та інші партнери залежно від теми і зацікавленості сторін) є важливим для визначення дійсних потреб і вирішення проблем. Брюссель несе частину відповідальності за вирішення проблем [2]. Відповідно Вишеградські офіційні діячі повинні продовжувати сприяти розширенню відносин між ЕС та Україною, лобіюючи простіший доступ українських громадян до ЕС та допомагаючи Україні виконувати необхідні умови, які висуває EC.

Враховуючи, що формування позиції щодо України поміж європейськими інститутами та різними країнами-членами ЕС повинно відбуватися узгоджено, держави Вишеграду можуть використовувати такі методи та інструменти впливу на формування політики ЕС, зокрема через:

1) запрошення на саміти та зустрічі представників «четвірки», міністерського рівня високопосадовців 3 інших країн ЕС, зокрема провідних держав-членів та тих, що можуть бути сталими чи ситуативними союзниками у формуванні європейської політики;

2) надсилання Спільних заяв урядам інших країн $\mathrm{EC}$, його спільним інститутам;

3) використання мережевого потенціалу спільних демократичних платформ, створених неурядовими організаціями центральноєвропейських країн у Брюсселі, у такий спосіб збільшуючи шанси своїх урядів просувати свої інтереси, а також репрезентуючи суспільні запити. 
Європейська Комісія (ЄК) підготувала 12 програм сусідства, у трьох з яких бере участь Україна разом із Вишеградськими партнерами:

1. Програма сусідства «Польща - Білорусь - Україна». В Україні поширюеться на Волинську, Закарпатську, Пьвівську області.

2. Програма сусідства «Угорщина - Словаччина - Україна». В Україні поширюється на Закарпатську область.

3. Україна приєдналась і до четвертого раунду транснаціональної програми CADSES (програма сприяе транснаціональній співпраці для Зони Центральної Адріатики - Дунаю - Південно-Східної Європи). В Україні поширюється на Волинську, Закарпатську, Івано-Франківську, Аьвівську, Одеську, Чернівецьку та Тернопільську області.

Основним принципом зовнішньої політики України щодо країн Центрадьної Європи має стати усвідомлення стратегічної важливості налагодження відносин 3 членами В4 не дише як з адвокатами поглиблення європейської інтеграції Києва, але як з партнерами, які поділяють єдину цивілізаційну модель та модель модернізації соціально-економічного життя [3]. Тим більше, що країни Вишеграду є об'єктивно зацікавленими у формуванні зони безпеки, стабільності, співробітництва та демократії в Україні вже тому, щоб «європеїзувати» цю «буферну зону» між ними і Росією i, отже, підвищити власну безпеку

Серед сучасних пріоритетів функціонування В4, які були визначені у 2011 р. у Братиславській декларації, релевантними до зовнішньополітичних пріоритетів України у сфері європейської інтеграції є завдання підтримки відповідних прагнень країн Східного партнерства, зокрема шляхом передачі «ноу-хау» демократизації, забезпечення енергетичної безпеки регіону методом диверсифікації джерел, шляхів та постачальників енергоносіїв, розвитку відповідної інфраструктури [3].

Запозичення досвіду демократизації, модернізації та європеїзації Україною у країнах Вишеградської групи має 
стати одним із основних пріоритетів у стосунках 3 центральноєвропейськими державами, тим більше, що це може подолати уявлення про євроінтеграційні наміри України як такі, що мають винятково економічний вимір у розумінні доступу до європейських ринків, інвестицій та технологій.

У публічних заявах, включно 3 нещодавніми, представники В4 наголошували на необхідності передачі досвіду європеїзації і реформ у сфері публічного управління. Зокрема, як заявляв тодішній Посол Польщі в Україні Г. Літвін у червні 2013 р., центральноєвропейські країни є готовими надати допомогу у сферах розвитку малого бізнесу, реформування місцевого самоврядування, тобто у тих перетвореннях, які були надзвичайно вдалими у «четвірці», однак їх вибір повинен визначатися представниками України [3].

Ураховуючи бажання країн Вишеграду передати досвід впровадження реформ, які були найбільш результативними серед усіх перетворень у центральноєвропейському регіоні, органам влади України важливо сформулювати тематичний перелік пріоритетів такого співробітництва.

Водночас бажаним є узгодження пріоритетів програм міжнародної допомоги країн В4 щодо України, що посидить ефект від їх реалізації та сприятиме підвищенню рівня ефективності використання виділених фінансових ресурсів.

Трансфер технології проведення реформ на різних рівнях, окрім механізму «Східного партнерства», двосторонніх програм, що, зокрема, підтримуються посольствами ЕС в Україні, може відбуватися посередництвом Міжнародного Вишеградського фонду. Таким чином, бенефіціарами технічної допомоги і водночас потенційними ініціаторами пріоритетів фонду можуть стати органи місцевого самоврядування, організації громадянського суспільства, освітні та наукові установи України, які можуть доповнити бачення урядових структур щодо «доданої вартості» від експертизи центрадьноєвропейських країн. Зокрема, найбільш повчальним може стати досвід Словаччини, оскільки саме в цій країні у період 1993-1998 рр. та 2006-2010 рр. сформувалися політичні умо- 
ви, які можна охарактеризувати як «дефіцит демократії», зростання популізму і корупції [3]. Зокрема, для українського суспільства і політикуму є корисним досвід налагодження діалогу між різними соціальними групами цієї країни та політичними акторами щодо європейської інтеграції, залучення громадянського суспільства до моніторингу стану виконання договірно-правових зобов' язань, прийнятих перед ЕС.

Однак такий трансфер демократизаціі і європеїзації буде мати результати лише у разі врегулювання відкритих та латентних політичних, етнічних та гуманітарних конфліктів чи, принаймні, нейтралізації їх найбільш гострих форм.

Зокрема, усвідомлюючи те, що етнічні та гуманітарні конфлікти складно подолати без зусиль щодо формування спільної центральноєвропейської ідентичності, упродовж останніх років високопосадовці В4 спрямовують зусилля на формування спільної політики збереження та просування культури народів, що проживають на цій території. Це було підтверджено і під час нещодавньої зустрічі міністрів культури [3], і Україні доцільно приєднатися до цієї діяльності.

Для уникнення розгортання конфліктів між суспільствами сусідніх країн на грунті історичної пам'яті доцільним є продовження спільних науково-дослідницьких проектів щодо оцінки спірних подій, зокрема у відносинах з Польщею, підтримку проведення семінарів, конференцій, форумів, інших акцій міжетнічного примирення, що зменшить можливості для маніпулювання історією та проведення електоральних кампаній на такій проблематиці.

Більш ніж активна політика Угорщини у питанні створення адміністративно-територіальної автономії угорців у суміжних країнах, включно з Україною, вимагає від Києва вироблення чіткої етнополітичної позиції у цьому питанні, що сприятиме більш виграшній позиції під час двосторонніх зустрічей і переговорів, включно проведення засідань двосторонніх комісій. Враховуючи також практику надання Угорщиною подвійного громадянства українцям, доцільним є започаткування політичного діалогу між урядами України 
та сусідніх держав щодо ставлення до інституту множинного громадянства, ініціювання укладення дво- чи багатосторонніх міжнародних договорів з країнами, щодо яких існують численні прецеденти набуття їх громадянства громадянами України, з приводу регулювання обов'язків громадян перед державами, а також щодо обміну інформацією для недопущення зайняття посад в органах державної влади та місцевого самоврядування особами, які мають подвійну лояльність.

Водночас запровадження безвізового режиму між Україною та ЕС потенційно зменшить кількість громадян, які бажають отримати громадянство сусідніх держав, оскільки основною мотивацією подібних дій, у частині випадків, є бажання вільного пересування по території Шенгенської зони.

Враховуючи, що Україна розглядається центральноєвропейськими країнами як складова регіональної безпеки, Київ може розглянути можливість знаходження формату співробітництва з Вишеградською бойовою групою під головуванням Польщі. Істотним елементом співпраці може бути розвиток прикордонної співпраці, контроль за повітряним простором, стажування офіцерів у штабах країн В4, спільні військові навчання, мовні і фахові навчання.

Беручи до уваги стан кризи, в якому знаходиться європейська економіка і господарство України, економізація відносин 3 країнами Вишеграду теж повинна бути в ряді головних тем двосторонніх і багатосторонніх відносин. Як відомо, економізація розглядається як складова т.зв. «прагматичного підходу» у зовнішній політиці України, який був підтверджений у Програмі економічних реформ на 2010-2014 рр. (червень 2010 р.). Цей підхід передбачав просування на міжнародних ринках продукції вітчизняного машинобудування, авіації, металургії, агропромислового комплексу, подолання тенденції до зменшення обсягів експорту. Іншою складовою курсу на зовнішньополітичну економізацію розгдядається залучення іноземних інвестицій в Україну.

Гасло економізації зовнішньої політики, незважаючи на його двояке сприйняття у середовищі політиків та експертів, 
позитивно корелюеться з проектами В4 щодо подальшої субрегіональної економічної інтеграції у Центральній та Східній Европі, які були вперше публічно озвучені у травні 2013 р. представниками Угорщини, яка 31 липня перебрала головування у групі. Таке об'єднання розглядається як запобіжник від негативних впливів європейських криз, підвищення конкурентоспроможності центральноєвропейських країн, сумарний ВВП яких становить орієнтовно 15-е місце серед світових економік [3], і не виключає галузеве залучення України.

У цьому контексті Департамент економічного співробітництва МЗС має здійснювати аналіз потреб українських імпортерів у центральноєвропейських ринках збуту та вітчизняної економіки в зарубіжних інвестиціях, сприяти разом 3 іншими управлінськими структурами, бізнес-асоціаціями організації спеціалізованих круглих столів чи презентацій сегментів української економіки, окремих бізнес-проектів. Взаємодія з країнами Вишеградської групи в економічній площині може також відбуватися у форматі асоційованого членства у Групі економічної промоції В4 на зовнішніх ринках. Беручи до уваги, що структура української економіки та господарств сусідніх країн є відмінною, це не повинно спричинити конфдікт інтересів

Потрібно брати до уваги, що країни В4 упродовж останніх років почали використовувати розширені формати співробітництва у питаннях, в яких зусилля лише цієї групи є недостатніми. Окрім вже згаданих питань інфраструктури, група долучила Румунію та Болгарію для розроблення Спільної стратегії просторового розвитку, що є можливими і для сусідньої України, яка займає проміжне положення між «четвіркою» і цим регіоном, принаймні на рівні прикордонних областей, використовуючи ресурси програмних «вікон» циклу 2014-2020 рр.

Враховуючи також, що транскордонне співробітництво розглядається як один із аспектів взаємодії у форматі В4, важдивими є зусилдя дипломатів України, представників органів влади західних областей щодо економізації функ- 
ціонування Карпатського єврорегіону та єврорегіону «Буг», зокрема використання існуючих формальних та неформальних 3в' язків для залучення інвестицій та донорських ресурсів.

У реаліях 2013 року Україна мала можливість скористатися новою риторикою В4, яка має намір «брендувати» Вишеградську четвірку як регіон, який є осередком специфічних центральноєвропейських цінностей і духу, в яких поєднуються традиціі, креативність та суспільна та міжетнічна солідарність. Окрім того, у період головування Польщі, який завершився 1 липня, та упродовж каденції Угорщини у фокус розвитку Вишеградської групи ставилось питання об'єднання зусиль країн-членів з метою підвищення потенціалу лобіювання спільних інтересів всередині ЕС, ресурсів, розвитку фізичної і людської інфраструктури, підвищення конкурентоспроможності регіону в умовах економічної кризи.

Таким чином, Україна могла скористатися цією ситуацією, зокрема підвищивши свою важливість для В4 як необхідного елементу регіональної економіки.

У цьому контексті, враховуючи, що Україна прийняла закон про ринок газу, який у цілому відповідає відповідним директивам ЕС, доцільною виглядае можливість участі у Дорожній карті формування регіонального газового ринку В4, яка була схвалена 16 червня 2013 р. прем'єр-міністрами цільових країн, і відповідно до якої «четвірка» домовлялася про розвиток спільної фізичної інфраструктури, спільний розгляд пропозицій від бізнес-консорціумів щодо будівництва нових мереж чи каналів надходження сировини, що вимагає створення форуму з питань інтеграції газових ринків [3]. Слід зазначити надзвичайно важливе значення міжрегіональної співпраці України з сусідніми країнами ЕС i, в першу чергу, у сфері узгодження та реалізації стратегічних пріоритетів регіональної політики, які тісно пов'язані 3 вирішенням завдань соціально-економічного розвитку та досягнення економічної безпеки.

Україна отримала унікальну можливість, підписавши Угоду про асоціацію з Европейським Союзом і доступ до 
європейських ринків, інвестицій та технологій. В контексті вступу в силу в 2016 році економічної частини Угоди про асоціацію з ЕС та поглиблення співпраці в інших аспектах актуальності набуває необхідність аналізу сучасного етапу інтеграції ЕС у всіх проявах останньої, що дасть можливість у загальних рисах окреслити можливі напрями подальшого поглиблення інтеграціі, оцінити їх вплив на євроінтеграційні перспективи потенційних претендентів на вступ. При цьому в колі особливого інтересу перебуває питання змін, спричинених у економічному, політичному житті ЕС після приєднання останніх 13 членів, оскільки це має віддалені насідки для об'єднання загалом, та, без сумніву, впливає на те, чи матиме Україна реальну перспективу членства в союзі.

Країни Вишеградської групи, окрім виконання ролі «адвоката» підписання цього документа і водночас стимулювання здійснення необхідних правових реформ і політичних кроків, у майбутньому можуть сприяти Україні в європеїзаціï іï політико-адміністративних процесів і модернізації соціально-економічного життя. Для реалізації цього проекту необхідною є політична воля та спільні зусилля обох сторін діалогу.

Застосування практики взаємодії наших найближчих західних сусідів і партнерів, апробованих у рамках «Вишеграду» механізмів, форм і видів співпраці спроможне сприяти нарощуванню зусиль щодо реалізації європейської інтеграційної стратегії Української держави, пошуку нею додаткових важелів, які могли б вплинути на поглиблення стосунків держави з Свросоюзом та нашими найближчими сусідами.

Проаналізований стан взаємовідносин України 3 членами Вишеградської четвірки, які є сусідами України на новому євросоюзівсько-українському кордоні, дає підстави стверджувати, що двостороння співпраця взаємовигідна i корисна.

Тісні історичні зв'язки та спільні зовнішньополітичні цілі сьогодення України та Вишеградської четвірки заклали основи для ефективного розвитку добросусідських відносин 
на сучасному етапі і створили можливості для подальшої масштабної взаємодії в майбутньому. Можна стверджувати, що вишеградсько-українські зв'язки є доволі збалансовані, про що свідчить успішна реалізація дво- та багатосторонніх домовленостей, досягнутих за результатами систематичних зустрічей на всіх рівнях. Все це створює міцний фундамент для подальшого розширення такого співробітництва на основі спільного врахування інтересів сторін.

Для України співробітництво 3 країнами Центрально-Східної Европи має важливе значення у зв'язку з нашою належністю до центрадьноєвропейської ідентичності, яка є дорогоцінним надбанням загальноєвропейської культури. Саме таке відчуття «спільноти» відіграє головну роль у зміцненні загальноєвропейської єдності в нинішній непростий для об'єднаної Европи період розвитку.

Зважаючи на проведений аналіз, можна з упевненістю визнати, що країни Вишеградської четвірки розвинули доволі гнучкі та різноманітні зовнішні стосунки й співробітництво з Україною в рамках вироблення й реалізації добросусідської політики ЄС. Мова йде про такі основні напрями співробітництва України та Вишеграду:

1) забезпечення солідарної підтримки країнами Вишеграду європейських інтеграційних прагнень України;

2) передача країнами Вишеграду досвіду їх європейської інтеграції Україні;

3) координація зовнішньополітичної діяльності України і Вишеградської групи на дво- та багатосторонній основі;

4) формування багаторівневого механізму співробітництва Вишеграду й України у формі участі українських представників у засіданнях різних Вишеградських структур та спеціально створених комісіях;

5) поширення програм Вишеградського фонду на Україну.

Більше того, змінюється система відносин всередині Вишеграду і Вишеградської четвірки з іншими країнами-членами Європейського співтовариства. Змінився і геополітичний статус Вишеградського об'єднання, що створює нові можли- 
вості єврорегіональної інтеграції для України, однак визначає і передачу повноважень наднаціонадьним структурам тобто Европейському Союзу.

Посилення співробітництва з В4 дасть змогу Україні інтегруватися до Європи через їі культурну, політичну, економічну та безпекову складові. Водночас для реалізації поставлених завдань потрібна політична воля та узгодженість позицій як нашої держави, так і країн-членів Вишеградської четвірки [2]. Бажаним є узгодження пріоритетів програм міжнародної допомоги країн В4 щодо України, що посилить ефект від їх реалізаціі та сприятиме підвищенню рівня ефективності використання виділених фінансових ресурсів. Для українського суспільства і політикуму є корисним зокрема досвід налагодження діалогу між іï різними соціальними групами та політичними акторами щодо европейської інтеграції, що вдалося здійснити центральноєвропейським країнам.

Одночасно потрібно вживати заходів, спрямованих на пом'якшення етнічних, історичних та культурних суперечностей, які склалися між країнами Центрально-Східної Европи. У цьому разі ефективним є інструмент використання різноманітних гуманітарних та освітніх проектів, що дають змогу сформувати певну центрадьноєвропейську ментальність, частиною якої повинна стати і Україна [5, с. 3-4; 6].

Подальша співпраця між Україною та країнами Вишеградської групи є важдивим чинником, який сприятиме успішній реалізації одного з основних пріоритетів зовнішньої політики України - курсу на європейську інтеграцію. Процес економічної інтеграції та політичної асоціації України з Европейським Союзом був би неможливий без надійної підтримки з боку наших європейських друзів і справжніх адвокатів України всередині СС, якими без перебільшення є країни В4. У середньостроковій перспективі відносини між Україною та державами Вишеградської четвірки дедалі більше набувають економічного характеру (з огляду на близьке географічне розташування) та сприяють налагодженню бізнес-зв' язків. Однак взаємодія із центральноєвропейськими 
країнами може набути нової якості після розв'язання чи принаймні пом' якшення етнічних, історико-культурних конфліктів, що виникли між суспільствами [5, с. 4]. За цих умов міжлюдські контакти, традиційно розвинені у цьому регіоні, в подальшому сприятимуть реалізації спільних гуманітарних проектів, формуванню атмосфери т.зв. центральноєвропейського духу, переосмисленню функцій Вишеграду та визначенню основних інструментів розвитку взаємовигідних відносин у форматі Україна-«Вишеград+». Тим більше, що така інтеграція має будуватися саме на посиленні регіонального складника співробітництва. Аише в такий спосіб, використовуючи євроінтеграційний досвід Угорщини, Польщі, Чехії та Словаччини, отримуючи експертну, дорадчу та технічну допомогу цих держав, ми матимемо можливість впевнено споглядати європейське майбутнє України.

\section{Список використаних джерел}

1. Зуб С.В. Україна-Вишеград: новий формат відносин // Геополітика України: історія і сучасність: збірник наукових праць. Вип. 1 (18). / ред. кол.: І.В.Артьомов (голова) та ін. - Ужгород: ДВНЗ «УЖНУ», 2017. - С. 175-183.

2. Зуб С.В. Інструменти розвитку взаємовигідних відносин у форматі Україна-«Вишеград+» // Наукові записки Тернопільського національного педагогічного університету імені Володимира Гнатюка. Серія: історія / за заг. ред. проф. І.С. Зуляка. - Тернопіль: Вид-во ТНПУ ім. В. Гнатюка, 2016. - Вип. 2. - Ч. 1. С. 147-150.

3. Кіш Є.Б. Центральна Европа в сучасній системі єврорегіональної інтеграції: монографія. - Ужгород: Ліра, 2008. - 440 с.

4. Дендьел М.О. Сучасний потенціал впливу Вишеградської групи на формування політики Європейського Союзу щодо України. URL: http://www.niss.gov.ua/articles/1127/.

5. Співробітництво з країнами Вишеградської четвірки як інструмент європейської інтеграції та модернізації України: аналіт. доп. / С. І. Мітряєва, М. О. Дендьел, А. Д. Стряпко, А. М. Крижевський [та ін.] - К.: НІСД, 2014. - 128 с. (Сер. «Міжнародні відносини», вип. 3). 
6. Турчин Я. Особливості партнерства між Україною та Вишеградською групою у контексті сучасних геополітичних викдиків // Українська національна ідея: реалії та перспективи розвитку. - 2015. - Вип. 27. - С. 144-152.

\section{REFERENCES}

1. Zub, S.V. (2017) Ukrayina-Vyshehrad: novyy format vidnosyn [Ukraine-Visegrad: a new format for relations]. Heopolityka Ukrayiny: istoriya i suchasnist': zbirnyk naukovykh prats'. Uzhhorod. S. 175-183.

2. Zub, S.V. (2016) Instrumenty rozvytku vzayemovyhidnykh vidnosyn $\mathrm{u}$ formati Ukrayina-«Vyshehrad+» [Tools for the development of mutually beneficial relations in the format Ukraine- "Visegrad +"]. Naukovi zapysky Ternopil's'koho natsional'noho pedahohichnoho universytetu imeni Volodymyra Hnatyuka. Seriya: istoriya. Ternopil. Vyp. 2. - CH. 1. S. 147-150.

3. Kish, YE.B. (2008) Tsentral'na Yevropa v suchasniy systemi yevrorehional'noyi intehratsiyi [Central Europe in the modern system of Euroregional integration]. Uzhhorod. $440 \mathrm{~s}$.

4. Lend'el, M.O. Suchasnyy potentsial vplyvu Vyshehrads'koyi hrupy na formuvannya polityky Yevropeys'koho Soyuzu shchodo Ukrayiny [Modern potential of the Visegrad Group influence on the formation of the European Union's policy towards Ukraine]. Retrieved from: http://www.niss.gov.ua/articles/1127/.

5. Spivrobitnytstvo z krayinamy Vyshehrads'koyi chetvirky yak instrument yevropeys'koyi intehratsiyi ta modernizatsiyi Ukrayiny [Cooperation with the Visegrad countries as an instrument of European integration and modernization of Ukraine]. S. I. Mitryayeva, M. O. Lend'el, A. D. Stryapko, A. M. Kryzhevs'kyy [ta in.] - K. 128 s.

6. Turchyn, YA. (2015) Osoblyvosti partnerstva mizh Ukrayinoyu ta Vyshehrads'koyu hrupoyu u konteksti suchasnykh heopolitychnykh vyklykiv [Peculiarities of the Partnership between Ukraine and the Visegrad Group in the Context of Modern Geopolitical Challenges]. Ukrayins'ka natsional'na ideya: realiyi ta perspektyvy rozvytku. Vyp. 27. S. 144-152. 